\title{
Operation of Symmetrical and Asymmetrical Two-Phase Induction Motor by Using 3-Leg Voltage Source Inverter
}

\author{
Sheetal Vishal Umredkar ${ }^{1 *}$, Abhishek Junghare ${ }^{2}$, and M.M. Renge ${ }^{3}$ \\ ${ }^{1}$ Assistant Professor, Department of Electrical Engineering, Shri Ramdeobaba College of Engineering \\ Nagpur-440013, India \\ ${ }^{2}$ Assistant Professor, Department of Electrical Engineering, S.B Jain Institute of technology and research \\ Nagpur-441501, India \\ ${ }^{3}$ Professor, Department of Electrical Engineering, Shri Ramdeobaba College of Engineering Nagpur- \\ 440013, India
}

Received January 27, 2018; Accepted March 15, 2018; Published April 30, 2018

The importance and demand of renewable energy have increased rapidly, especially due to the fact that the fossil fuels are reducing at an alarming rate. Out of the existing sources of renewable energies, solar energy has been very popular due to obvious abundance and convenience. The predominant use of electrical energy is heating, ventilation and air conditioning in residential and industrial sector. Single phase induction motor is widely used for such low-power appliances like pumps, compressors, agriculture equipment's and blowers. In order to avoid losses and low-starting torque, we intend to use the single-phase induction motor as an asymmetrical two-phase induction motor, which will run on a two-phase supply yielding better efficiency, speed control and power factor. If a three-phase supply is available, Scott-T transformer can be used to get two-phase supply. However, if there is only single-phase supply available, two-phase inverter with Sine Pulse Width Modulation (SPWM) technique can be used. This paper presents the method for twophase supply using the 3-leg voltage source inverter (VSI) which is used to supply asymmetrical and symmetrical two-phase induction motor. The 16 bit microcontroller dsPIC is used for SPWM signal generation.

Keywords: Two-phase motor; Two-phase supply; Scott-T transformer; Sine PWM; 3-Leg voltage source Inverter (VSI)

\section{Introduction}

Single-phase induction motor is the most widely used motor in home appliances, agricultural equipment, pumps, compressors, blowers and industries for low-power applications. This motor is widely adopted for domestic applications because it uses single-phase AC source with constant frequency which is easily available. In domestic applications, it is used with great advantages, but its performance is menial compared to the poly-phase induction motor due to low-rated power, zero starting torque and high torque harmonics $[1,2]$.

Two different techniques are used to control single-phase induction motor: scalar control and vector control. In scalar control technique, two parameters are changed simultaneously. The speed can be varied by changing the supply frequency, but this 
causes changes in the impedances which result in changes in the current. If the current is small, torque developed by the motor decreases. If the frequency decreases or the voltage increases, the coils may burn or saturation may occur in the iron of coils. To avoid these problems, it is necessary to vary the voltage and frequency at the same time. Scalar control is a more economical and simpler technique, but it gives unsatisfactory performance of the drives with dynamic behavior and slow transient response. In vector control, it is possible to control two parameters independently and satisfy the requirements of dynamic behavior of the drives. Its main drawback is complexity and higher cost. Vector control of three-phase induction motor is easy as compared to single phase-phase induction motor, because single-phase induction motor has different parameters of both the windings (i.e., main and auxiliary winding) $[3,4]$.

In the proposed system, we have designed symmetrical and asymmetrical twophase induction motors. In symmetrical two-phase induction motor, parameters of both the windings are same, while they are different in case of asymmetrical motor. For this study, we used scalar control for both symmetrical and asymmetrical motors. However, vector control of symmetrical two-phase motor can be simple and more accurate and should be preferred over scalar method for better dynamic performance in actual industrial applications [5]. Performance of single-phase induction motor is improved by using voltage source inverter (VSI), and we should use the single-phase induction motor (SPIM) as an asymmetrical two-phase induction motor (TPIM) by removing capacitor. Two-phase motor can be introduced in the place of single-phase induction motor with additional advantages such as more efficiency, better power factor and better speed control. There is no need to replace the existing single-phase motor, because it can be tweaked to work as two-phase motor to improve the performance of the drive by removing capacitor connected in the circuit and fed by two-phase supply. Two-phase supply can be generated with the help of three-phase supply and Scott-T transformer. But for the domestic applications, household single-phase supply is already available. So either conversion of supply to three-phase is needed or any other suitable setup is required. This complexity can be reduced with the help of microcontroller. This paper presents the method to get two-phase supply using the 3-leg VSI, which is used to power asymmetrical and symmetrical two-phase induction motor. A dsPIC microcontroller [6] is used to generate Sine Pulse Width Modulation (SPWM) switching signal for running the two-phase induction motor and controlling the speed of motor. The control is performed by SPWM technique with voltage source inverter and tested by open loop control.

\section{Two-phase Supply}

The simple method to obtain two-phase supply is by using the Scott-T transformer from conventional three-phase supply. The Scott-T is made by two different single-phase transformers with different tapping ratios. The connections are made in such manner that Scott-T transformer gives two single-phase outputs which are called as Main output and Teaser output. The Main and Teaser output are $90^{\circ}$ out of phase [7]. Connections consist of 1:1 center-tapped ratio of Main transformer $\mathrm{T}_{1}$, and $86.6 \%$ ratio of Teaser transformer $\mathrm{T}_{2}$. The center-tapped side of $\mathrm{T}_{1}$ transformer is connected between two of the phases in the three-phase side. Centre tap is then connected to one end of higher turn side of $\mathrm{T}_{2}$, and the other ends to remaining phases [8]. The remaining side of transformers $T_{1}$ and $T_{2}$ 
is the side at which two-phase output is obtained and two-phase motor can be connected [7].

Two-phase induction motor is connected between phase- 1 and phase- 2 . But these types of supply cause imbalance in the system side due to power quality issues. The devices are sensitive to the power quality connected in the system and can cause maloperation. Also in the household applications, the three-phase supply is not available as per requirement of above circuitry. With respect to industrial applications, the high cost of Scott-T transformer is a concern. Thus, more efficient and low cost technique to obtain two-phase supply is by using micro-controller.

\section{Modeling of Two-phase Induction Motor}

Single phase induction motors are constructed in the form of two-phase motors, with two stator windings in space quadrature [8]. The main and auxiliary windings are quite different in the following aspects: different turns, wire size and turns distributions. These differences cause unbalanced winding currents. Under balanced operating conditions, a symmetrical two-phase motor can be analyzed using technique for threephase motors with slight modification [9].

Under unbalanced conditions, the stator-mmf wave travels $90^{\circ}$ in space in a time interval corresponding to a $90^{\circ}$ phase change of applied voltage, with the direction of travel depending on the phase sequence of the currents.

Mathematical model of two-phase induction motor is given below,

$$
\left[\begin{array}{c}
\lambda_{m} \\
\lambda_{a} \\
\lambda_{r 1} \\
\lambda_{r 2}
\end{array}\right]=\left[\begin{array}{cccc}
L_{m} & 0 & L_{m, r 1(\theta m e)} & L_{m, r 2(\theta m e)} \\
0 & L_{a} & L_{a, r 1(\theta m e)} & L_{a, r 2(\theta m e)} \\
L_{m, r 1(\theta m e)} & L_{a, r 1(\theta m e)} & L_{r} & 0 \\
L_{m, r 2(\theta m e)} & L_{a, r 2(\theta m e)} & 0 & L_{r}
\end{array}\right]\left[\begin{array}{c}
i_{m} \\
i_{a} \\
i_{r 1} \\
i_{r 2}
\end{array}\right]
$$

where

$\boldsymbol{\theta}_{\mathbf{m e}}$ : Rotor angle measured in electrical radians.

$\mathbf{L}_{\mathbf{m}} \& \mathbf{L}_{\mathbf{a}}$ :Self-inductance of the main and auxillary winding resp.

$\mathbf{L}_{\mathbf{m}, \mathbf{r} \mathbf{1}}\left(\boldsymbol{\theta}_{\mathbf{m e}}\right)$ : Mutual inductance between the main winding and equivalent rotor winding 1 .

$\mathbf{L}_{\mathbf{m}, \mathbf{r} 2}\left(\boldsymbol{\theta}_{\mathbf{m e}}\right)$ : Mutual inductance between the main winding and equivalent rotor winding 2.

$\mathbf{L}_{\mathbf{a}, \mathbf{r} 1}\left(\boldsymbol{\theta}_{\mathbf{m e}}\right)$ : Mutual inductance between the auxiliary winding and equivalent rotor winding 1 .

$\mathbf{L}_{\mathbf{a}, \mathbf{r} 2}\left(\boldsymbol{\theta}_{\mathbf{m e}}\right)$ : Mutual inductance between the auxiliary winding and equivalent rotor winding 2.

Assume a sinusoidal distribution of air gap flux, the mutual inductance between the main winding and the rotor is

$$
\begin{aligned}
& \mathrm{L}_{\mathrm{m}, \mathrm{r} 1}\left(\theta_{\mathrm{me}}\right)=\mathrm{L}_{\mathrm{m}, \mathrm{r}} \cos \left(\theta_{\mathrm{me}}\right) \\
& \mathrm{L}_{\mathrm{m}, \mathrm{r} 2}\left(\theta_{\mathrm{me}}\right)=-\mathrm{L}_{\mathrm{m}, \mathrm{r}} \sin \left(\theta_{\mathrm{me}}\right)
\end{aligned}
$$

where

$\mathrm{L}_{\mathrm{m}, \mathrm{r}}$ : Amplitude of mutual inductance

$$
\mathrm{L}_{\mathrm{a}, \mathrm{r} 1}\left(\theta_{\mathrm{me}}\right)=\mathrm{L}_{\mathrm{a}, \mathrm{r}} \sin \left(\theta_{\mathrm{me}}\right)
$$




$$
\begin{aligned}
& \mathrm{L}_{\mathrm{a}, \mathrm{r} 2}\left(\theta_{\mathrm{me}}\right)=\mathrm{L}_{\mathrm{a}, \mathrm{r}} \cos \left(\theta_{\mathrm{me}}\right) \\
& \mathrm{L}_{\mathrm{a}, \mathrm{r}}=\mathrm{aL}_{\mathrm{a}, \mathrm{r}}
\end{aligned}
$$

Self-inductance of the magnetizing branch can be written as the sum of leakage inductance $L_{m, 1}$ and a magnetizing inductance $L_{m}$

$$
\mathrm{L}_{\mathrm{m}}=\mathrm{L}_{\mathrm{m}, 1}+\mathrm{L}_{\mathrm{m}}
$$

Then the self-inductance of the auxiliary winding can be written as

$$
L_{a}=L_{a, 1}+a^{2} L_{m}
$$

The voltage equations for this machine can be written in terms of the winding currents and flux linkage as

$$
\begin{aligned}
& v_{\mathrm{m}}=i_{m} R_{m}+\frac{d \lambda_{m}}{d t} \\
& v_{a}=i_{a} R_{a}+\frac{d \lambda_{a}}{d t} \\
& v_{r 1}=0=i_{r 1} R_{r}+\frac{d \lambda_{r 1}}{d t} \\
& v_{r 2}=0=i_{r 2} R_{r}+\frac{d \lambda_{r 2}}{d t}
\end{aligned}
$$

where $R_{m}, R_{a}$, and $R_{r}$ are the resistances of the main, auxiliary and rotor windings, respectively.

Electro-magnetic torque of the motor can be written as

$$
\begin{aligned}
& \mathrm{T}_{\text {mech }}= \mathrm{i}_{\mathrm{m}} \mathrm{i}_{\mathrm{r} 1} \frac{\mathrm{dL}, \mathrm{r} 1\left(\theta_{\mathrm{me}}\right)}{\mathrm{d} \theta_{\mathrm{m}}}+\mathrm{i}_{\mathrm{m}} \mathrm{i}_{\mathrm{r} 2} \frac{d L_{\mathrm{m}, \mathrm{r} 2}\left(\theta_{\mathrm{me}}\right)}{\mathrm{d} \theta_{\mathrm{m}}}+\mathrm{i}_{\mathrm{a}} \mathrm{i}_{\mathrm{r} 1} \frac{d L_{\mathrm{a}, \mathrm{r} 1}\left(\theta_{\mathrm{me}}\right)}{\mathrm{d} \theta_{\mathrm{m}}} \\
&+\mathrm{i}_{\mathrm{a}} \mathrm{i}_{\mathrm{r} 2} \frac{\mathrm{dL_{ \textrm {a } , \mathrm { r } 2 }}\left(\theta_{\mathrm{me}}\right)}{\mathrm{d} \theta_{\mathrm{m}}} \\
& \mathrm{T}_{\mathrm{mech}}=\left[\frac{\mathrm{poles}}{2}\right]\left[-\mathrm{L}_{\mathrm{m}, \mathrm{r}}\left(\mathrm{i}_{\mathrm{m}} \mathrm{i}_{\mathrm{r} 1} \sin \theta_{\mathrm{me}}+\mathrm{i}_{\mathrm{m}} \mathrm{i}_{\mathrm{r} 2} \cos \theta_{\mathrm{me}}\right)\right. \\
&+\left(\mathrm{L}_{\mathrm{a}, \mathrm{r}}\left(\mathrm{i}_{\mathrm{a}} \mathrm{i}_{\mathrm{r} 1} \cos \theta_{\mathrm{me}}-\mathrm{i}_{\mathrm{a}} \mathrm{i}_{\mathrm{r} 2} \sin \theta_{\mathrm{me}}\right)\right]
\end{aligned}
$$

where

$\theta_{\mathrm{m}}=\left[\frac{2}{\text { poles }}\right] \theta_{\mathrm{me}}$ is the rotor angle in radians.

Assuming steady-state operation, with constant mechanical speed $\mathrm{w}_{\text {me }}$, corresponding to slip $\mathrm{s}$ and constant supply frequency $\mathrm{w}_{\mathrm{e}}$. Using above assumption, the rotor currents will be at frequencies $\mathrm{w}_{\mathrm{r}}=\mathrm{w}_{\mathrm{e}}-\mathrm{w}_{\mathrm{me}}=\mathrm{sw}_{\mathrm{me}}$ (produced by the stator positive-sequences field) and $\mathrm{w}_{\mathrm{r}}=\mathrm{w}_{\mathrm{e}}+\mathrm{w}_{\mathrm{me}}=(2-\mathrm{s}) \mathrm{w}_{\mathrm{me}}$ (produced by the stator negative-sequences field).

Using equation (11) and (12) to eliminate the rotor currents, the main and auxiliary-winding flux-linkage/current relationships of equation (1) can be written as

$$
\begin{aligned}
& \overline{\lambda_{\mathrm{m}}}\left[\mathrm{L}_{\mathrm{m}}-\mathrm{j} \mathrm{L}_{\mathrm{m}, \mathrm{r}}^{2}\left(\overline{\mathrm{k}^{+}}+\overline{\mathrm{k}^{-}}\right)\right] \overline{\mathrm{I}_{\mathrm{m}}}+\mathrm{L}_{\mathrm{m}, \mathrm{r}} \mathrm{L}_{\mathrm{a}, \mathrm{r}}\left(\overline{\mathrm{k}^{+}}-\overline{\left.\mathrm{k}^{-}\right)} \overline{\mathrm{I}_{\mathrm{m}}}\right. \\
& \overline{\lambda_{\mathrm{a}}=-\mathrm{L}_{\mathrm{m}, \mathrm{r}} \mathrm{L}_{\mathrm{a}, \mathrm{r}}\left(\overline{\mathrm{k}^{+}}-\overline{\left.\mathrm{k}^{-}\right)} \overline{\mathrm{I}_{\mathrm{m}}+\left[\mathrm{L}_{\mathrm{a}}-\mathrm{J}_{\mathrm{a}, \mathrm{r}}^{2}\left(\overline{\mathrm{k}^{+}}+\overline{\mathrm{k}^{-}}\right)\right] \overline{\mathrm{I}_{\mathrm{a}}}}\right.}
\end{aligned}
$$

where 


$$
\overline{\mathrm{k}^{+}}=\frac{\mathrm{sw}_{\mathrm{e}}}{2\left(\mathrm{R}_{\mathrm{r}}+j s \mathrm{w}_{\mathrm{e}} \mathrm{L}_{\mathrm{r}}\right)} \mathrm{and}^{-}=\frac{(2-\mathrm{s}) \mathrm{w}_{\mathrm{e}}}{2\left(\mathrm{R}_{\mathrm{r}}+\mathrm{j}(2-\mathrm{s}) \mathrm{w}_{\mathrm{e}} \mathrm{L}_{\mathrm{r}}\right)}
$$

The voltage equations using equation (9) and (10) as,

$$
\begin{aligned}
& \overline{\mathrm{V}_{\mathrm{m}}}=\overline{\mathrm{I}_{\mathrm{m}}} \mathrm{R}_{\mathrm{m}}+j \mathrm{w}_{\mathrm{e}} \overline{\lambda_{\mathrm{m}}} \\
& \overline{\mathrm{V}_{\mathrm{a}}}=\overline{\mathrm{I}_{\mathrm{a}}} \mathrm{R}_{\mathrm{a}}+j \mathrm{w}_{\mathrm{e}} \overline{\lambda_{\mathrm{a}}}
\end{aligned}
$$

The rotor currents consist of positive and negative-sequence components. The complex amplitudes of the positive-sequence and negative-sequence components at frequency $\mathrm{sw}_{\mathrm{e}}$ and $(2-\mathrm{s}) \mathrm{w}_{\mathrm{e}}$, respectively, are given by

$$
\begin{aligned}
& \overline{\mathrm{I}_{\mathrm{r} 1}{ }^{+}}=\frac{-j s w_{\mathrm{e}}\left[\mathrm{L}_{\mathrm{m}, \mathrm{r}} \overline{\mathrm{I}_{\mathrm{m}}}+\mathrm{j}\right] \mathrm{L}_{\mathrm{a}, \mathrm{r}} \overline{\mathrm{I}}_{\mathrm{a}}}{2\left(\mathrm{R}_{\mathrm{r}}+\mathrm{j} \mathrm{sw}_{\mathrm{e}} \mathrm{L}_{\mathrm{r}}\right)} \\
& \overline{\mathrm{I}_{\mathrm{r} 2}{ }^{+}}=\overline{\mathrm{I}_{\mathrm{r} 1}{ }^{+}} \\
& \begin{array}{l}
\overline{\mathrm{I}_{\mathrm{r} 1}^{+}}=\frac{-\mathrm{j}(2-\mathrm{s}) \mathrm{w}_{\mathrm{e}}\left[\mathrm{L}_{\mathrm{m}, \mathrm{r}} \overline{\mathrm{I}_{\mathrm{m}}}-\mathrm{j}\right] \mathrm{L}_{\mathrm{a}, \mathrm{r}} \overline{\mathrm{I}_{\mathrm{a}}}}{2\left(\mathrm{R}_{\mathrm{r}}+\mathrm{j}(2-\mathrm{s}) \mathrm{w}_{\mathrm{e}} \mathrm{L}_{\mathrm{r}}\right)} \\
\overline{\mathrm{I}_{\mathrm{r} 2}{ }^{+}}=j \overline{\mathrm{I}_{\mathrm{r} 1}{ }^{+}}
\end{array}
\end{aligned}
$$

\section{Equivalent Circuit of Two-Phase Induction Motor}

The TPIM equivalent circuit models take into account core loss representing with $\left(R_{C}\right)$ in parallel across the forward and backward field impedances as shown in Fig. 1 [9]. Design of the induction motor model depends on determination of the parameters. The parameters can be determined by performing direct current test, no-load test and locked rotor test on the motor.
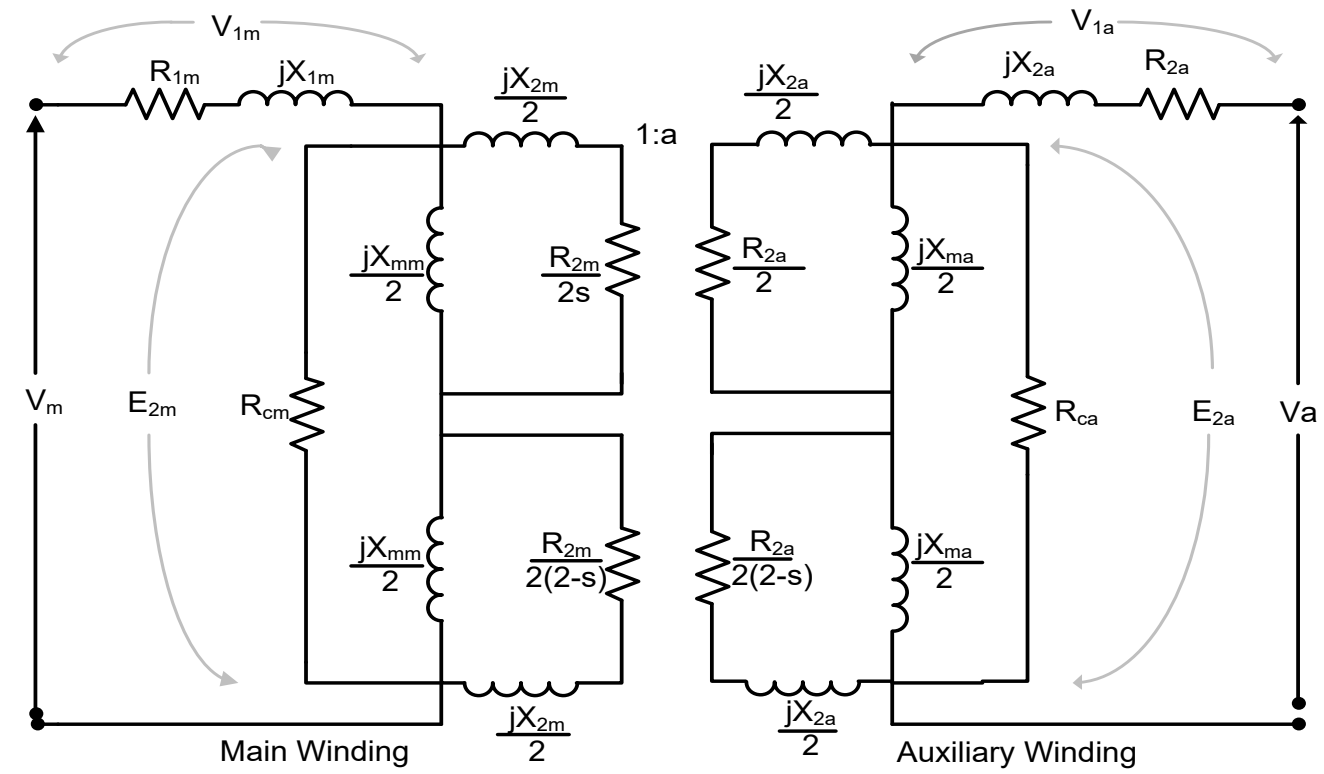

Fig. 1. Equivalent circuit of two-phase induction motor

Fig. 1 shows the equivalent circuit for TPIM. $V_{m}, I_{m}, V_{a}, I_{a}, \mathrm{~s}, \mathrm{a}, \mathrm{R}_{\mathrm{cm}}, \mathrm{R}_{\mathrm{ca}}$ are main winding and auxiliary winding voltages, currents, slip, turn ratio, resistances showing the main and auxiliary winding core losses, respectively. Impedance calculation of main winding is given by following equations, 


$$
\begin{aligned}
& Z_{m}=Z_{1 m}+Z_{2 m} \\
& Z_{1 m}=\left(R_{1 m}+j X_{1 m}\right) \\
& Z_{2 m}=\frac{R_{c m}\left(Z_{f m}+Z_{b m}\right)}{R_{c m}+Z_{f m}+Z_{b m}} \\
& Z_{f m}=\frac{\frac{j X_{m m}}{2}\left(\frac{R_{2 m}}{2 s}+j \frac{X_{2 m}}{2}\right)}{\frac{j X_{m m}}{2}+\left(\frac{R_{2 m}}{2 s}+j \frac{X_{2 m}}{2}\right)} \\
& Z_{b m}=\frac{\frac{j X_{m m}}{2}\left(\frac{R_{2 m}}{2(2-s)}+j \frac{X_{2 m}}{2}\right)}{\frac{j X_{m m}}{2}+\left(\frac{R_{2 m}}{2(2-s)}+j \frac{X_{2 m}}{2}\right)}
\end{aligned}
$$

The main winding voltage and current equations of the circuit are

$$
\begin{aligned}
& V_{m}=V_{1 m}+E_{2 m} \\
& I_{m}=\frac{V_{m}}{Z_{m}}
\end{aligned}
$$

Similar to main winding, impedance of the auxiliary winding is given by the following equations.

$$
\begin{aligned}
& Z_{a}=Z_{1 a}+Z_{2 a} \\
& Z_{1 a}=\left(R_{1 a}+j X_{1 a}\right) \\
& Z_{2 a}=\frac{R_{c a}\left(Z_{f a}+Z_{b a}\right)}{R_{c a}+Z_{f a}+Z_{b a}} \\
& Z_{f a}=\frac{\frac{j X_{m a}}{2}\left(\frac{R_{2 a}}{2 s}+j \frac{X_{2 a}}{2}\right)}{\frac{j X_{m a}}{2}+\left(\frac{R_{2 a}}{2 s}+j \frac{X_{2 a}}{2}\right)} \\
& Z_{b a}=\frac{j X_{m a}}{2}\left(\frac{R_{2 a}}{2(2-s)}+j \frac{X_{2 a}}{2}\right) \\
& \frac{j X_{m a}}{2}+\left(\frac{R_{2 a}}{2(2-s)}+j \frac{X_{2 a}}{2}\right)
\end{aligned}
$$

The main winding voltage and current equations of the circuit are,

$$
\begin{aligned}
& \mathrm{V}_{\mathrm{a}}=\mathrm{V}_{1 \mathrm{a}}+\mathrm{E}_{2 \mathrm{a}} \\
& \mathrm{I}_{\mathrm{a}}=\frac{\mathrm{V}_{\mathrm{a}}}{\mathrm{Z}_{\mathrm{a}}} \\
& \mathrm{V}_{\mathrm{a}}=\mathrm{aV}_{\mathrm{m}}
\end{aligned}
$$

where $\mathrm{P}_{\text {cus }}$ and $\mathrm{P}_{\mathrm{c}}$ are the stator copper loss and core loss. 


\section{Inverter Circuit}

The block diagram of proposed system is shown in Fig. 2. The single-phase AC supply can be converted to DC by simply using bridge rectifier and filter circuitry. The 3leg voltage source inverter is used to convert DC to two-phase AC supply. The 3-leg voltage source inverter consists of six insulated-gate bipolar transistor (IGBT) switches. The switching pulses for the IGBT are obtained by dsPIC micro-controller. The SPWM is used as modulation technique for IGBT. By using the inverter, the TPIM can be made to operate over a wide range of speed by adjusting the frequency [5].

\section{Proposed System}

Fig. 2 shows the proposed system, in which 3-leg voltage source inverter is connected to two-phase induction motor that is developed in the core of single-phase induction motor [8]. The 3-leg voltage source inverter is used for conversion of DC to $\mathrm{AC}$ by using sinusoidal pulse width modulation (SPWM) technique. A dsPIC microcontroller is used to generate switching pulses for the switches of the inverter by using SPWM technique. With the advent of renewable energy resources, photovoltaic (PV) array is often considered as the best power source for DC supplies. The DC input to the inverter can be given by a solar panel through boost converters. The connected system can have various applications like solar based water pumping system, cooling system and many others. For this study, it is necessary to obtain higher voltage for threeleg VSI driving TPIM with rated flux. Therefore, a boost converter can be included to achieve sufficient DC link voltage and increase the system efficiency [10].

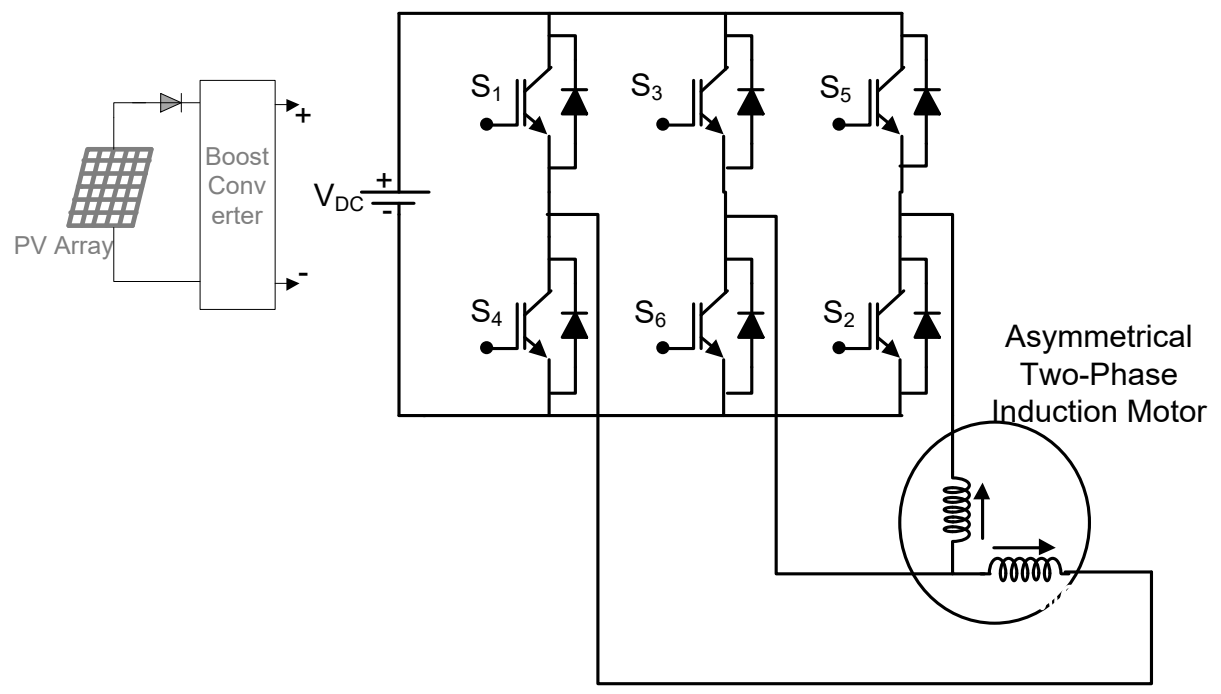

Fig. 2. Proposed System

\section{Two-Leg Voltage Source Inverter}

The two-leg two-phase inverter connected to two-phase Induction Motor, it consists of 4 switches with 2-leg inverter and center tapped capacitor supplied with DC supply $[11,12]$. DC supply is either fed from solar panel with the help of boost converter or with the help of diode rectifier fed from single-phase AC supply. SPWM pulses fed to second leg has phase shift of $90^{\circ}$. Main winding and auxiliary winding of two-phase 
induction motor are fed from two legs of two-phase voltage source inverter. The neutral or common is given to capacitor link.

Many researchers have worked on the 2-leg voltage source inverter but practically it has its own problem of total harmonic distortion of current. The output voltage obtained at phases of two-phase induction motor in case of 2-leg inverter is lower, which results in lower efficiency of motor.

\section{Three-Leg Voltage Source Inverter}

The modern technique is to use 3-leg voltage source inverter 3-leg voltage source inverter is constructed as shown in Fig. 2 [1]. The inverter consists of 6 IGBT switches. Two switches and two diodes are used for a boost rectifier for power factor correction, and the other four switches and four diodes are used for the 2-leg inverter. Such circuits have been applied to compact SPIM drives to improve the input power factor and reduce the output voltage harmonics. A 3-leg voltage source inverter providing two-phase outputs is increasingly attractive for two-phase drive applications due to good dc voltage utilization. When compared with the 2-leg voltage source inverter for a two-phase induction motor, the 3-leg voltage source inverter offers reduction in the motor current ripple and more or less 20\% higher output phase voltages. Also, the problem of unbalanced voltages across two DC-link capacitors is absent for the 3-leg voltage source inverter.

The voltages $\mathrm{V}_{\mathrm{a} 0}, \mathrm{~V}_{\mathrm{b} 0}$ and $\mathrm{V}_{\mathrm{c} 0}$ are defined by following equations,

$$
\begin{aligned}
& V_{a 0}=\mathrm{m} \sin \left(\mathrm{w}_{\mathrm{e}} \mathrm{t}\right) \\
& \mathrm{V}_{\mathrm{b} 0}=\mathrm{m} \sin \left(\mathrm{w}_{\mathrm{e}} \mathrm{t}-\frac{\pi}{2}\right) \\
& \mathrm{V}_{\mathrm{c} 0}=\mathrm{m} \sin \left(\mathrm{w}_{\mathrm{e}} \mathrm{t}-\pi\right)
\end{aligned}
$$

where

m: modulation index

The switching signal pattern of the three-phase reference voltages is derived from equation (41) to equation (43) and compared with the triangular carrier signal. If the reference voltage is lower than the triangular carrier, the status of switching is OFF. Otherwise if reference voltage is higher than or equal to the triangular reference voltage, the status of switch is ON. This modulation technique is called as Sine pulse width modulation (SPWM).

The reference voltage can be adjusted by varying values of modulation index $\mathrm{m}$ from 0 to 1 , while the magnitude of triangular carrier voltage $\left(\mathbf{V}_{\mathbf{t r i}}\right)$ is to be 1 . The modulation index is kept at 0.95 . The switching frequency of IGBT switches is kept at $1000 \mathrm{~Hz}$, which results in the output $\mathrm{AC}$ voltage at $50 \mathrm{~Hz}$. The frequency of testing signal is kept at $50 \mathrm{~Hz}$, as per Indian standard.

\section{Gate Driver Circuit}

The Gate driver circuit consists of main parts

1. AC supply

2. Rectifier

3. Filter Capacitor

4. dsPIC Microcontroller

5. Buffer SN7407 


\section{Driver TLP250}

The rectifier circuit is used to covert $\mathrm{AC}$ to $\mathrm{DC}$ as per requirement. The dsPIC microcontroller works on the 3.3 volt DC and its output voltage is also a 3.3 volt DC. The buffer SN7407 works on 5 volt DC, while optocoupler TLP 250 needs 15 volt DC. The optocoupler IC provides necessary isolation between dsPIC microcontroller [6] circuit and IGBT switches. In this way, the gate pulse magnitude with voltage nearly equal to 14.5 volt is given to IGBT for its operation. The grounding of 15 volt supply for optocoupler TLP250, switches $\mathrm{S}_{1}$ and $\mathrm{S}_{4}, \mathrm{~S}_{3}$ and $\mathrm{S}_{6}, \mathrm{~S}_{5}$ and $\mathrm{S}_{2}$ should not be same, otherwise it would result in short-circuit. The grounding for switch $\mathrm{S}_{4}, \mathrm{~S}_{2}$ and $\mathrm{S}_{6}$ can be made common for 15 volt DC.

\section{Experimental Setup}

Fig. 3 shows the experimental setup of the 3-leg voltage source inverter with following rating of asymmetrical two-phase Induction motor are $0.25 \mathrm{HP}, 230 \mathrm{~V}$, $50 \mathrm{~Hz}, \mathrm{R}_{1 \mathrm{~m}}=2 \Omega, \mathrm{X}_{1 \mathrm{~m}}=\mathrm{X}_{2 \mathrm{~m}}^{\prime}=3 \Omega, \mathrm{R}_{2 \mathrm{~m}}=4 \Omega, \mathrm{X}_{\mathrm{mm}}=60 \Omega, \mathrm{R}_{\mathrm{c}}=600 \Omega$

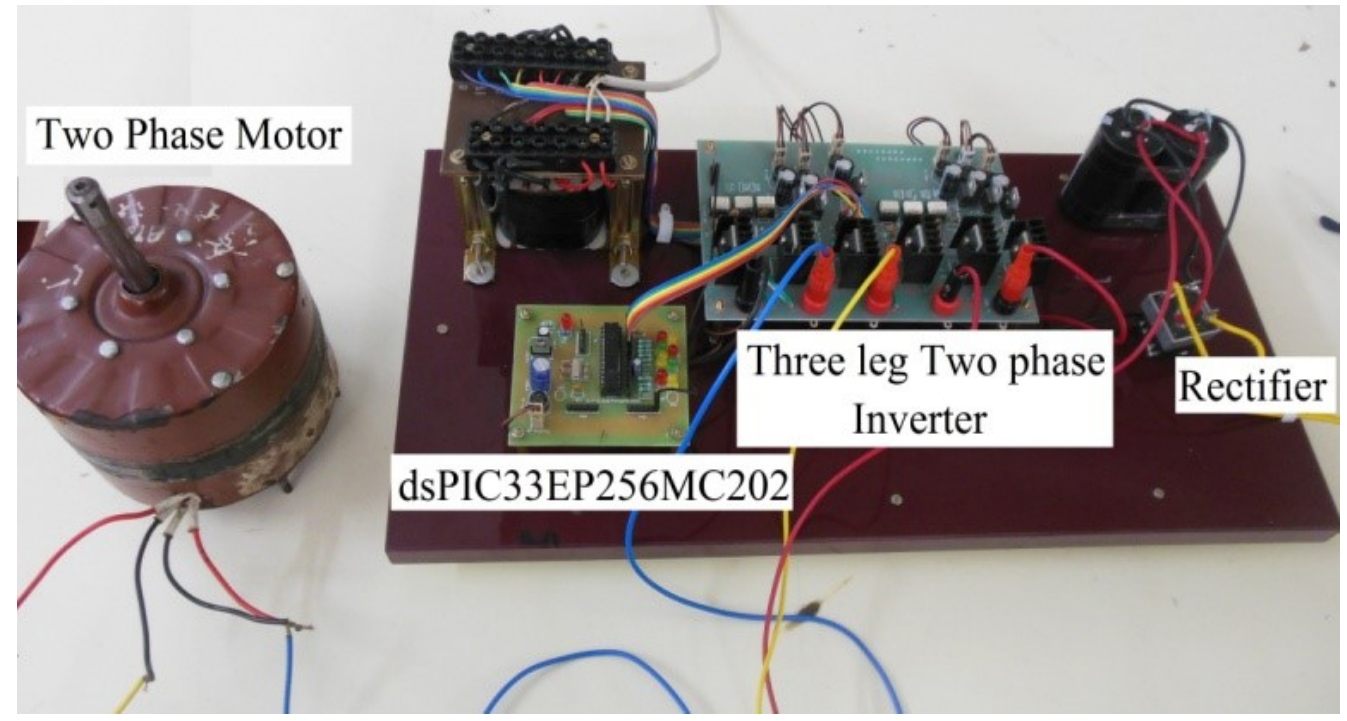

Fig. 3. Experimental setup

Single-phase supply is given to the rectifier, which is easily available in households and small factories. The rectifier converts it to DC and feds DC supply to 3leg two-phase inverter which converts it into two-phase AC supply. The IGBT switches are used in the inverter for switching, whose switching pulses are fed from dsPIC microcontroller IC.

\section{Results}

The switching pulses for upper switches $S_{1}, S_{3}$ and $S_{5}$ are given in Fig. 4 and obtained with the help of the dsPIC microcontroller. The complementary pulses are given to $\mathrm{S}_{4}, \mathrm{~S}_{6}$, and $\mathrm{S}_{2}$, respectively. The phase shift of $90^{\circ}$ is obtained between two windings. 
Fig. 5 shows the line voltage at the output terminal of inverter. Fig. 6 shows the speed signal of motor at no load. Motor is running at 1425 RPM.

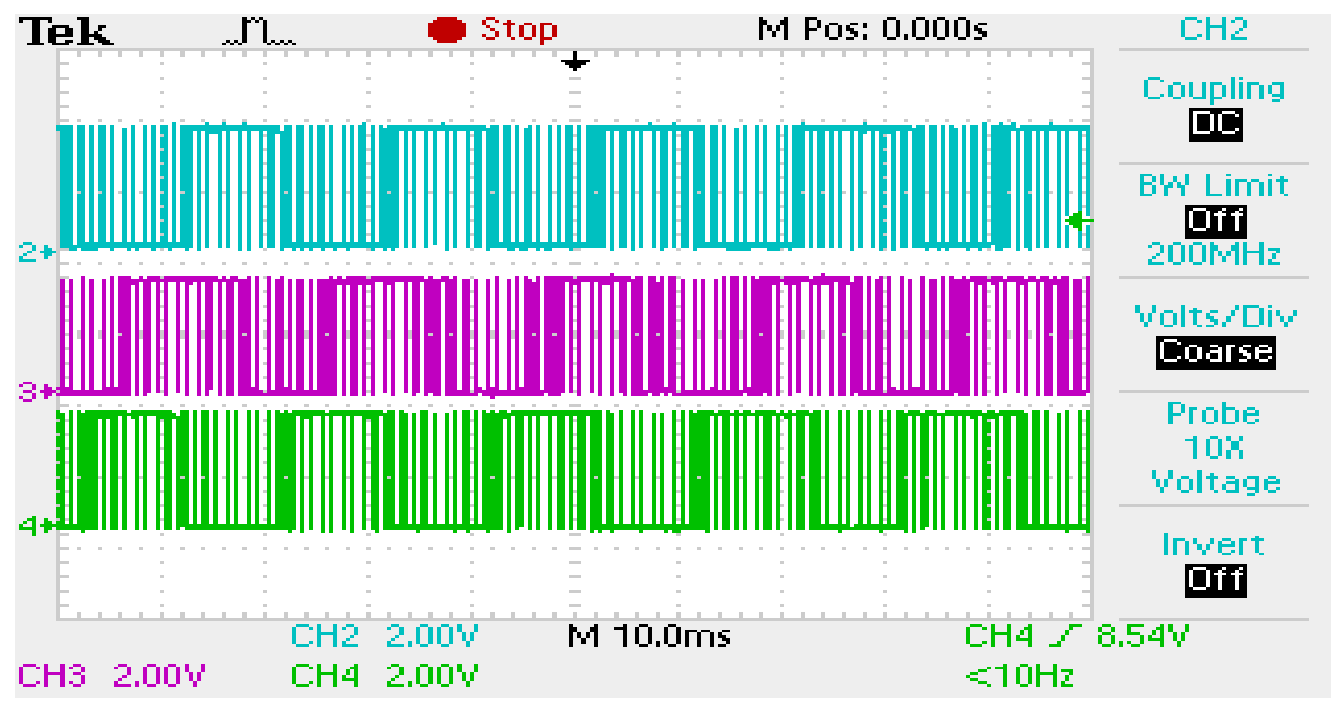

Fig. 4. Switching Signal for upper switches

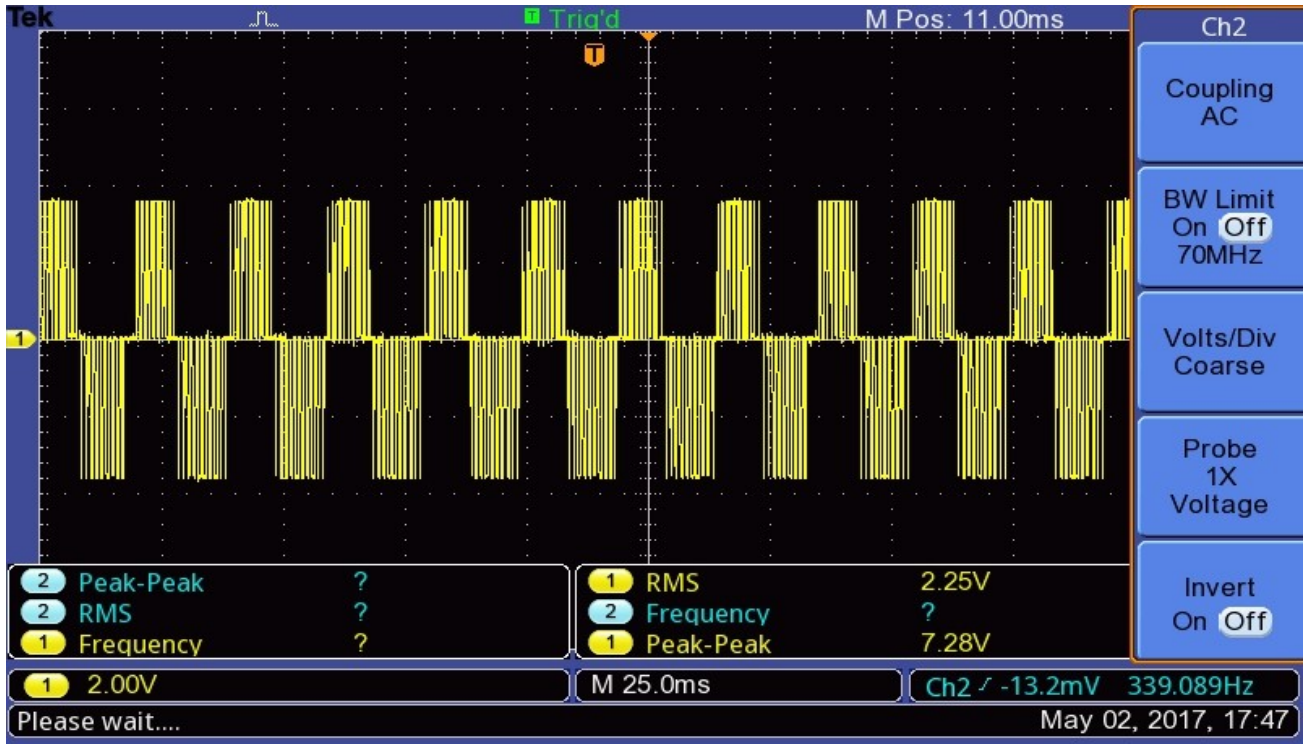

Fig. 5. Line Voltage 


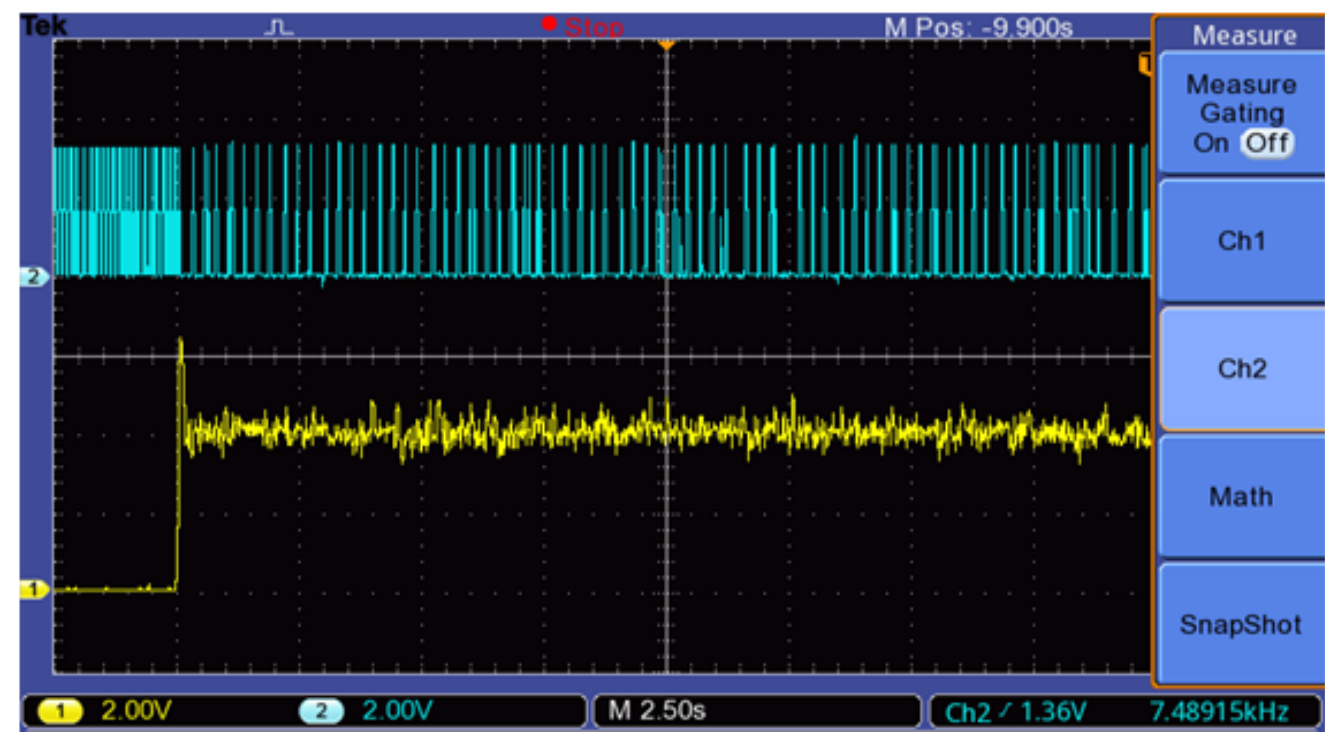

Fig. 6. Speed of two-phase induction motor at no load

Table 1. Results with asymmetrical induction motor

\begin{tabular}{|c|c|c|c|c|c|}
\hline \multirow{2}{*}{$\begin{array}{c}\text { Sr. } \\
\text { No. }\end{array}$} & \multicolumn{2}{|c|}{ ASYMMETRICAL INDUCTION MOTOR } \\
\cline { 2 - 6 } & $\begin{array}{l}\text { Voltage } \\
\text { (Volts) }\end{array}$ & $\begin{array}{c}\text { With Capacitor } \\
\text { (Wower } \\
\text { (Watts) }\end{array}$ & $\begin{array}{c}\text { Speed } \\
\text { (RPM) }\end{array}$ & $\begin{array}{c}\text { Without Capacitor } \\
\text { (Watts) }\end{array}$ & $\begin{array}{c}\text { Speed } \\
(\text { RPM) }\end{array}$ \\
\hline 1 & 120 & -- & -- & 54 & 360 \\
\hline 2 & 130 & 62.77 & 580 & 64 & 570 \\
\hline 3 & 150 & 79.66 & 790 & 78 & 770 \\
\hline 4 & 190 & 108 & 1040 & 109 & 1062 \\
\hline 5 & 210 & 133 & 1178 & 135.3 & 1198 \\
\hline 6 & 230 & 139.5 & 1230 & 145 & 1320 \\
\hline
\end{tabular}

Table 1 shows the readings of asymmetrical induction motor with and without capacitor. Table 2 shows the readings of symmetrical induction motor with and without capacitor.

Table 2. Results with symmetrical induction motor

\begin{tabular}{|c|c|c|c|c|c|}
\hline \multirow{2}{*}{$\begin{array}{c}\text { Sr. } \\
\text { No. }\end{array}$} & \multicolumn{3}{|c|}{ SYMMETRICAL INDUCTION MOTOR } \\
\cline { 2 - 6 } & \multirow{2}{*}{$\begin{array}{c}\text { Voltage } \\
\text { (Volts) }\end{array}$} & $\begin{array}{c}\text { With Capacitor } \\
\text { Power } \\
\text { (Watts) }\end{array}$ & $\begin{array}{c}\text { Speed } \\
\text { (RPM) }\end{array}$ & $\begin{array}{c}\text { Power } \\
\text { (Watts) }\end{array}$ & $\begin{array}{c}\text { Speed } \\
\text { (RPM) }\end{array}$ \\
\hline 1 & 80 & -- & -- & 28.8 & 390 \\
\hline 2 & 130 & 72.5 & 490 & 74.6 & 535 \\
\hline 3 & 150 & 94 & 640 & 96.6 & 690 \\
\hline 4 & 190 & 134.4 & 1050 & 136.6 & 1150 \\
\hline 5 & 210 & 156.6 & 1156 & 159.8 & 1220 \\
\hline 6 & 230 & 168 & 1226 & 172.3 & 1296 \\
\hline
\end{tabular}


The experimental results shown in Table 1 and Table 2 indicate that the performance of symmetrical two-phase motor is satisfactory as compared to asymmetrical motor without capacitor.

The total costing was estimated from two conversion methods. It is clear that twophase supply with 3-leg voltage source inverter system is very economical and efficient technique with huge difference of approximately $\$ 22$ than conventional Scott-T transformer system as shown in Table 3.

Table 3. Total Costing

\begin{tabular}{|c|c|c|c|}
\hline \multicolumn{2}{|c|}{$\begin{array}{c}\text { Two-Phase } \\
\text { (With Scott-T Transformer) }\end{array}$} & \multicolumn{2}{|c|}{$\begin{array}{c}\text { Two-Phase } \\
\text { (With 3-Leg Inverter) }\end{array}$} \\
\hline $\begin{array}{lr}\text { Motor } & \text { Core, } \\
\text { Stator and } \\
\text { Rotor }\end{array}$ & $\$ 12$ & $\begin{array}{lr}\text { Motor } & \text { Core, } \\
\text { Stator } & \text { and } \\
\text { Rotor } & \end{array}$ & $\$ 12$ \\
\hline Winding Cost & $\$ 8$ & Winding Cost & $\$ 8$ \\
\hline $\begin{array}{l}\text { Scott-T } \\
\text { Transformer }\end{array}$ & $\$ 32$ & 3-Leg Inverter & $\$ 10$ \\
\hline Total & $\$ 52$ & Total & $\$ 30$ \\
\hline
\end{tabular}

\section{Conclusion}

In the developing countries, the motor pumps consume substantial portion of total electricity. Single-phase induction motor is commonly used in household, industries and agriculture for pumping purpose. Same single-phase induction motor can be upgraded to two-phase motor by the technique described in this paper. The use of two-phase induction motor gives high starting torque, variable speed and high rated power. The two-phase mode of operation achieves increased rated torque causing more power in the same frame size and higher efficiency resulting in less running cost. By using a 3-leg voltage source inverter for obtaining two-phase supply, the supply for motor can be obtained more economically and efficiently.

\section{CONFLICTS OF INTEREST}

The authors declare that there is no conflict of interests regarding the publication of this paper.

\section{REFERENCES}

[1] K. Kaenthong, V. Tipsuwanporn, A. Numsomran and A. Charean, "Asymmetrical Two-Phase Induction Motor Speed Controlled with 3-Leg Voltage Source Inverter," IEEE International Conference on Industrial Technology (ICIT), pp. 640645, 2015. DOI: 10.1109/icit.2015.7125170

[2] D.G. Holmes and A. kotsopoulos, "Variable speed control of single and two phase induction motors using a three phase voltage source inverter" IEEE Industrial 
Applications Society annual meeting conference records, pp.613-620, 1993. DOI: 10.1109/IAS.1993.298887

[3] Md Ayubur Rahman Khan and Md Quamrul Ahsan, "Development and Performance Analysis of a Two-Phase Induction Motor in the Frame and Core of a Single-Phase Induction Motor," 8th International Conference on Electrical and Computer Engineering, pp. 469-472, 2014. DOI: 10.1109/ICECE.2014.7026982

[4] F.A.S. Neves, E.B.S. Filho, J.M.S. Cruz, R.P. Landim, Z.D. Lins and A.G.H. Accioly, "Single-Phase Induction Motor Drives with Direct Torque Control," IEEE 2002 28th Annual Conference of the Industrial Electronics Society. IECON 02, pp.241-246, 2002. DOI: 10.1109/IECON.2002.1187514

[5] Do-Hyun Jang "Problems Incurred in a Vector-Controlled Single-Phase Induction Motor, and a Proposal for a Vector-Controlled Two-Phase Induction Motor as Replacement," IEEE Transaction on Power Electronics, vol. 28, no. 1, pp. 526 536, 2013. DOI: 10.1109/TPEL.2012.2199772

[6] Microchip Technology, "DS70000657H, 16-Bit Microcontrollers and Digital Signal Controllers with High-Speed PWM, Op Amps and Advanced Analog”, 2013. $\quad$ http://ww1.microchip.com/downloads/en/DeviceDoc/70000657H.pdf (accessed on 4/30/2018)

[7] J. Parmar, "Scott-T Connection of Transformer", 2012. https://electricalnotes.wordpress.com/2012/05/06/scott-t-connection-oftransformer/ (accessed on 4/30/2018)

[8] P. Kongsuk and V. Kinnares, "Loss Modeling of Three-leg Volltage Source Inverter fed Asymmetrical Two-phase Induction Motor", $18^{\text {th }}$ International Conference on Electrical Machines and systems(ICEMS), 2015. DOI: 10.1109/ICEMS.2015.7385130

[9] A.E. Fitzgerald, C. Kingsley, S.D. Umans and B. James, Electric Machinery. New York: McGraw-Hill; 2003.

[10] E. Hayakwong and V. Kinnares, "PV powered three-leg VSI fed asymmetrical parameter type two-phase induction motor," 2014 17th International Conference on Electrical Machines and Systems (ICEMS), Hangzhou, 2014, pp. 3220-3225. DOI: 10.1109/ICEMS.2014.7014047

[11] D.H. Jang, "PWM methods for two-phase inverters," IEEE Ind. Appl. Mag., vol. 13, no. 2, pp.50-61, 2007. DOI: 10.1109/MIA.2007.322258

[12] C.G. Veinott, Theory and Design of Small Induction Motors, New York: McGrawHill, 1959.

Article copyright: (C) 2018 Sheetal Vishal Umredkar, Abhishek Junghare and M. M. Renge. This is an open access article distributed under the terms of the Creative Commons Attribution 4.0 International License, which permits unrestricted use and distribution provided the original author and sources are credited.

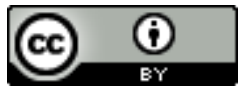

